Article

\title{
Ecotoxicological Evaluation of Methiocarb Electrochemical Oxidation
}

\author{
Annabel Fernandes ${ }^{1, * \mathbb{D}}$, Christopher Pereira ${ }^{1}$, Susana Coelho ${ }^{2,3} \mathbb{D}$, Celso Ferraz ${ }^{2,3}$, \\ Ana C. Sousa ${ }^{4, * \mathbb{D}}$, M. Ramiro Pastorinho ${ }^{3,5,6}$, Maria José Pacheco ${ }^{1}$, Lurdes Ciríaco ${ }^{1}$ \\ and Ana Lopes 1 D \\ 1 FibEnTech-UBI, Department of Chemistry, Universidade da Beira Interior, 6201-001 Covilhã, Portugal; \\ christophersp1992@gmail.com (C.P.); mjap@ubi.pt (M.J.P.); lciriaco@ubi.pt (L.C.); analopes@ubi.pt (A.L.) \\ 2 Health Sciences Research Centre (CICS), Universidade da Beira Interior, 6200-506 Covilhã, Portugal; \\ susana_coelho_1@hotmail.com (S.C.); celsoferraz16@gmail.com (C.F.) \\ 3 NuESA-Health and Environment Study Unit, Faculty of Health Sciences, Universidade da Beira Interior, \\ 6200-506 Covilhã, Portugal; rpastorinho@uevora.pt \\ 4 CICECO-Aveiro Institute of Materials, Department of Chemistry, Universidade de Aveiro, \\ 3810-193 Aveiro, Portugal \\ 5 Department of Biology, Universidade de Évora, 7002-554 Évora, Portugal \\ 6 Comprehensive Health Research Centre (CHRC), 7002-554 Évora, Portugal \\ * Correspondence: annabelf@ubi.pt (A.F.); anasousa@ua.pt (A.C.S.); Tel.: +351275241329 (A.F.); \\ +351234370200 (A.C.S.)
}

Received: 21 September 2020; Accepted: 21 October 2020; Published: 22 October 2020

\begin{abstract}
The ecotoxicity of methiocarb aqueous solutions treated by electrochemical oxidation was evaluated utilizing the model organism Daphnia magna. The electrodegradation experiments were performed using a boron-doped diamond anode and the influence of the applied current density and the supporting electrolyte $\left(\mathrm{NaCl}\right.$ or $\left.\mathrm{Na}_{2} \mathrm{SO}_{4}\right)$ on methiocarb degradation and toxicity reduction were assessed. Electrooxidation treatment presented a remarkable efficiency in methiocarb complete degradation and a high potential for reducing the undesirable ecological effects of this priority substance. The reaction rate followed first-order kinetics in both electrolytes, being more favorable in a chloride medium. In fact, the presence of chloride increased the methiocarb removal rate and toxicity reduction and favored nitrogen removal. A 200× reduction in the acute toxicity towards D. magna, from 370.9 to 1.6 toxic units, was observed for the solutions prepared with $\mathrm{NaCl}$ after $5 \mathrm{~h}$ treatment at $100 \mathrm{~A} \mathrm{~m}^{-2}$. An increase in the applied current density led to an increase in toxicity towards D. magna of the treated solutions. At optimized experimental conditions, electrooxidation offers a suitable solution for the treatment and elimination of undesirable ecological effects of methiocarb contaminated industrial or agricultural wastewaters, ensuring that this highly hazardous pesticide is not transferred to the aquatic environment.
\end{abstract}

Keywords: acute toxicity; Daphnia magna; electrochemical oxidation; emerging contaminants; methiocarb

\section{Introduction}

Emerging contaminants including some pharmaceuticals, personal care products and pesticides are a cause of concern due to their ubiquity in the aquatic environment and their potential for causing deleterious ecological effects [1-4]. This has led the European Union to establish a surveillance mechanism for the monitoring of substances that show a possible risk to the environment. In 2018, the Commission Implementing Decision (EU) 2018/840 was published, establishing a watch list of substances for Union-wide monitoring in the field of water policy, which includes hormones, antibiotics and pesticides [5]. 
One of the priority substances identified by the Commission Implementing Decision (EU) 2018/840 watch list is methiocarb (MC), $\mathrm{C}_{11} \mathrm{H}_{15} \mathrm{NO}_{2} \mathrm{~S}$, a carbamate pesticide employed in agriculture worldwide, which has been detected in natural waters and in wastewaters [5-9]. Due to MC and some of its metabolites' high toxicity, the World Health Organization classified MC as a highly hazardous pesticide, being also strictly regulated by the European Union [10-12]. Although the presence of methiocarb in waters and wastewaters at concentrations ranging from $\mathrm{n} \mathrm{L} \mathrm{L}^{-1}$ to $\mu \mathrm{g} \mathrm{L}{ }^{-1}$ is usually associated with its use, the industrial production of pesticides and herbicides generates a large volume of wastewaters with a high concentration of these pollutants that, if not properly treated, will also contaminate the water bodies $[13,14]$.

According to the literature, conventional wastewater treatments are uncapable of removing pollutants such as MC $[6,11]$. Thus, new treatment technologies have been studied to achieve the complete degradation of these contaminants to environmentally benign, non-toxic and biodegradable products and prevent their discharge in the aquatic environment [15-19]. Methiocarb oxidation through $\mathrm{ClO}_{2}, \mathrm{NaOCl}$ and $\mathrm{NH}_{2} \mathrm{Cl}$ has been studied by Qiang et al. [20] and Tian et al. [21,22]. The authors found that, despite the effective elimination of MC, a significant increase in toxicity due to the formation of more toxic degradation products occurred. By applying a vacuum ultraviolet/ultraviolet (VUV/UV) process in the degradation of several pesticides including MC, Yang et al. [23] observed a reduction in the toxicity of the solutions although the pesticides' mineralization rates were considerably lower than their degradation rates. Cruz-Alcalde et al. [11] studied the removal of MC by ozonation and observed that during the degradation experiments, direct ozone reaction was effective to remove $\mathrm{MC}$ but not its formed intermediates whereas hydroxyl radicals could oxidize all species. In fact, treatment technologies based on oxidation through hydroxyl radicals have been widely studied because hydroxyl radicals are one of the most powerful oxidizing species that are able to react unselectively and instantaneously with the surrounding organic pollutants [24]. Among these technologies, electrochemical processes have received great attention due to their versatility, ease in operation and, specially, their high efficiency in the degradation of recalcitrant compounds $[17,25]$. Several authors have reported the removal of pesticides and herbicides using different electrochemical methods including electrochemical oxidation (EO), electro-Fenton (EF), photoelectro-Fenton (PEF) and electrochemical peroxidation [13,14,26-28]. In the degradation of solutions containing $100 \mathrm{mg} \mathrm{L}^{-1}$ of the herbicide clopyralid, Santos et al. [14] found that, among EO with electrogenerated hydrogen peroxide, EF and PEF processes, PEF led to the most attractive results with almost a complete transformation of clopyralid in inorganic ions. In a different study, Silva et al. [26] applied an EO process utilizing dimensionally stable anodes (DSA) to degrade the insecticide imidacloprid at a concentration of approximately $25 \mathrm{mg} \mathrm{L}^{-1}$ and achieved its complete oxidation ( $100 \%$ mineralization). According to these authors, the imidacloprid degradation occurred via direct anodic oxidation and $\mathrm{Cl}_{2}$-mediated oxidation and the breakdown of the insecticide's molecular structure and formation of short chain compounds occurred before its complete mineralization. In a study performed by Martínez-Huitle et al. [28], the performance of different anode materials, $\mathrm{Pb} / \mathrm{PbO}, \mathrm{Ti} / \mathrm{SnO}_{2}$ and a boron-doped diamond anode (BDD), was evaluated during the electrochemical oxidation of the pesticide methamidophos at a concentration of $50 \mathrm{mg} \mathrm{L}^{-1}$. A few authors have found that, using $\mathrm{Pb} / \mathrm{PbO}_{2}$ and $\mathrm{Ti} / \mathrm{SnO}_{2}$, formaldehyde appeared as a product of the reaction, giving evidence of an indirect mineralization mechanism. However, when BDD was used, formaldehyde production was not detected and the formation of phosphate was observed instead, indicating the complete mineralization of methamidophos. In fact, EO using a BDD anode has been regarded as the electrochemical process of choice with outstanding degradation results that are due to the higher oxidation ability of BDD compared with other anode materials [29-33].

Although the application of the EO process in the treatment of waters and wastewaters appears as an attractive alternative for the degradation of biorefractory or priority pollutants such as pesticides and herbicides, the influence of the EO treatment in the toxicity of the treated solutions is not well known because the removal of the contaminants might not always correspond to a quantitative reduction of the toxic effects. The physicochemical and biological parameters usually determined 
to evaluate the quality of wastewaters are not sufficient to assess the toxicity to organisms where ecotoxicological tests with aquatic organisms are required to better characterize the toxicity removal and prevent undesirable ecological effects in the aquatic environment caused by wastewater discharge [34]. Hence, the present work aims to fill this gap by evaluating the ecotoxicity of methiocarb solutions treated by EO using the freshwater crustacean Daphnia magna as the model species, as endorsed by international organizations including the American Society for Testing and Materials (ASTM, USA), the Organization for Economic Cooperation and Development (OECD, France) and the International Organization for Standardization (ISO, Switzerland). In the particular case of the highly toxic pesticide methiocarb, there are no studies addressing its degradation by electrochemical oxidation with a subsequential ecotoxicological evaluation. Thus, electrochemical oxidation experiments utilizing a BDD anode were performed with MC aqueous solutions at a concentration of $20 \mathrm{mg} \mathrm{L}^{-1}$. In order to assess the influence in the toxicity results of two major experimental conditions that greatly affect the EO performance, MC degradation was carried out at two different applied current densities (j), 100 and $300 \mathrm{~A} \mathrm{~m}^{-2}$, utilizing two different supporting electrolytes, $\mathrm{NaCl}$ and $\mathrm{Na}_{2} \mathrm{SO}_{4}$. Although the $\mathrm{MC}$ concentrations reported for waters and wastewaters are in the range of $\mathrm{ng} \mathrm{L}^{-1}$ to $\mu \mathrm{g} \mathrm{L}^{-1}$, the concentration of $20 \mathrm{mg} \mathrm{L}^{-1}$ was selected for this study with the aim of evaluating the ability of the EO process to reduce the high toxicity of this priority substance in an extreme-case scenario and attending to the concentrations found in the literature for electrochemical studies involving pesticides and herbicides. In addition, in the cases where membrane filtration processes are utilized to purify the effluents, the concentrations in the permeate may reach values much higher than those usually found at the entrance of the effluent treatment plants.

\section{Materials and Methods}

\subsection{Methiocarb Aqueous Solutions Composition and Characterization}

The composition and characterization of the methiocarb aqueous solutions used in this study are described in Table 1. MC solutions were prepared in ultrapure water obtained with a Milli-Q system using the methiocarb PESTANAL ${ }^{\circledR}$, analytical standard (CAS Number 2032-65-7), purchased from Sigma-Aldrich. As the MC aqueous solution did not have enough electrical conductivity to pursue with the electrochemical experiments at the applied current densities, the addition of a background electrolyte was required. Two different salts were studied as background electrolytes, sodium sulfate anhydrous (CAS Number 7757-82-6) of $99.7 \%$ purity and sodium chloride ACS reagent (CAS Number 7647-14-5), purity $\geq 99.0 \%$. Both were purchased from Sigma-Aldrich. The concentration of added salt was set as the minimum required to perform the EO assays at the highest applied current density studied ( $300 \mathrm{~A} \mathrm{~m}^{-2}$ ), which was found to be $250 \mathrm{mg} \mathrm{L}^{-1}$, corresponding to an increase of the solution's electrical conductivity to approximately $500 \mu \mathrm{S} \mathrm{cm}^{-1}$.

Table 1. Composition and characterization of the methiocarb aqueous solutions used in the experiments.

\begin{tabular}{|c|c|c|c|}
\hline \multicolumn{2}{|c|}{ Solution } & \multirow{2}{*}{$\frac{\mathrm{MC}+\mathrm{Na}_{\mathbf{2}} \mathrm{SO}_{\mathbf{4}}}{20}$} & \multirow{2}{*}{$\frac{\mathbf{M C}+\mathbf{N a C l}}{20}$} \\
\hline Composition & Methiocarb & & \\
\hline \multirow[t]{2}{*}{$\mathrm{mg} \mathrm{L}^{-1}$} & $\mathrm{Na}_{2} \mathrm{SO}_{4}$ & 250 & \\
\hline & $\mathrm{NaCl}$ & - & 250 \\
\hline \multicolumn{2}{|c|}{ Chemical oxygen demand/mg L $\mathrm{L}^{-1}$} & $43 \pm 1$ & $43 \pm 1$ \\
\hline \multicolumn{2}{|c|}{ Total organic carbon $/ \mathrm{mg} \mathrm{L}^{-1}$} & $11.6 \pm 0.4$ & $11.8 \pm 0.5$ \\
\hline \multicolumn{2}{|c|}{ Total nitrogen $/ \mathrm{mg} \mathrm{L}^{-1}$} & $1.23 \pm 0.03$ & $1.24 \pm 0.04$ \\
\hline \multicolumn{2}{|c|}{$\mathrm{pH}$} & $5.45 \pm 0.03$ & $5.28 \pm 0.03$ \\
\hline \multicolumn{2}{|c|}{ Conductivity $/ \mu \mathrm{S} \mathrm{cm}^{-1}$} & $437 \pm 5$ & $514 \pm 5$ \\
\hline \multirow[t]{2}{*}{ Acute toxicity/ } & $\mathrm{EC}_{50}(48 \mathrm{~h})$ & $0.21 \%$ & $0.27 \%$ \\
\hline & $\mathrm{TU}^{1}$ & 470.4 & 370.9 \\
\hline
\end{tabular}

${ }^{1} \mathrm{TU}$-toxic units $\left(\mathrm{TU}=\left(1 / \mathrm{EC}_{50}\right) \times 100, \mathrm{TU}>100\right.$ : highly toxic, $10<\mathrm{TU}<100$ : very toxic, $1<\mathrm{TU}<10$ : toxic, $\mathrm{TU}<1$ non-toxic [35]). 


\subsection{Electrodegradation Experiments}

The EO experiments aimed to study the influence of the composition of the supporting electrolyte, of the applied current density and of the electrolysis duration/applied electric charge on the toxicity reduction towards Daphnia magna and on the removal rate of methiocarb, total organic carbon (TOC) and total nitrogen (TN). Thus, the EO assays were conducted at room temperature $\left(22-25^{\circ} \mathrm{C}\right)$ in batch mode with stirring (250 rpm), using an open, undivided and cylindrical glass cell $(250 \mathrm{~mL}$ of capacity) and $200 \mathrm{~mL}$ of solution. A commercial Si/BDD anode purchased from Neocoat and a stainless-steel cathode, each one with an immersed area of $10 \mathrm{~cm}^{2}$, were utilized as electrodes. They were placed in parallel with an inter-electrode gap of $0.3 \mathrm{~cm}$ and were centered in the electrochemical cell. The experiments, utilizing the solutions described in Table $1, \mathrm{MC}+\mathrm{Na}_{2} \mathrm{SO}_{4}$ and $\mathrm{MC}+\mathrm{NaCl}$, were performed at two different applied current densities, 100 and $300 \mathrm{~A} \mathrm{~m}^{-2}$, which was the electric current supplied by a GW, Lab DC, model GPS-3030D (0-30 V, 0-3 A) power source. For the applied current density of $100 \mathrm{~A} \mathrm{~m}^{-2}, 5 \mathrm{~h}$ and $6 \mathrm{~h}$ duration assays were performed, corresponding to applied charges of 1.80 and $2.16 \mathrm{kC}$, respectively. For the experiments run at $300 \mathrm{~A} \mathrm{~m}^{-2}$, the assays had $3 \mathrm{~h}$ duration, corresponding to $3.24 \mathrm{kC}$ of applied charge. Samples were collected each hour for physicochemical determinations to monitor the experiments. Additionally, in the experiments run at $300 \mathrm{~A} \mathrm{~m}^{-2}$, a sample was collected after $20 \mathrm{~min}$ of starting the assay corresponding to an applied charge of $0.36 \mathrm{kC}$, which was the same reached after $1 \mathrm{~h}$ by the experiments run at $100 \mathrm{~A} \mathrm{~m}^{-2}$. Toxicological assays were only performed for the initial $\left(\mathrm{MC}+\mathrm{Na}_{2} \mathrm{SO}_{4}\right.$ and $\mathrm{MC}+$ $\mathrm{NaCl})$ and final samples $\left(\mathrm{MC}+\mathrm{Na}_{2} \mathrm{SO}_{4}-100 \mathrm{~A} \mathrm{~m}^{-2}-1.8 \mathrm{kC}(5 \mathrm{~h}), \mathrm{MC}+\mathrm{Na}_{2} \mathrm{SO}_{4}-100 \mathrm{~A} \mathrm{~m}^{-2}-2.16 \mathrm{kC}(6 \mathrm{~h})\right.$, $\mathrm{MC}+\mathrm{Na}_{2} \mathrm{SO}_{4}-300 \mathrm{~A} \mathrm{~m}^{-2}-3.24 \mathrm{kC}(3 \mathrm{~h}), \mathrm{MC}+\mathrm{NaCl}-100 \mathrm{~A} \mathrm{~m}^{-2}-1.8 \mathrm{kC}(5 \mathrm{~h}), \mathrm{MC}+\mathrm{NaCl}-100 \mathrm{~A} \mathrm{~m}^{-2}-2.16$ $\mathrm{kC}(6 \mathrm{~h})$ and $\left.\mathrm{MC}+\mathrm{NaCl}-300 \mathrm{~A} \mathrm{~m}^{-2}-3.24 \mathrm{kC}(3 \mathrm{~h})\right)$. For the kinetic study, assays with $1 \mathrm{~h}$ duration were run with samples being collected every $15 \mathrm{~min}$.

All of the EO assays were performed at least in duplicate and results presented are mean values of all of the determinations performed.

\subsection{Toxicological Assays}

The freshwater crustacean Daphnia magna Strauss, Clone K6, was used in the toxicological assays. The daphnids were obtained from a stock culture maintained in the laboratory under standardized conditions. The animals were reared at a constant temperature $\left(20 \pm 1^{\circ} \mathrm{C}\right)$ and photoperiod (16:8 h light/dark) in ASTM (American Society of Testing Materials) hard water. The culture medium was changed every other day during weekdays and was supplemented with seaweed extract. The daphnids were fed daily with the green algae Raphidocelis subcapitata $\left(3.0 \times 10^{5}\right.$ cells $\left.\mathrm{mL}^{-1}\right)$. From this stock culture, individual daphnids were transferred to $100 \mathrm{~mL}$ beakers prior to the beginning of the tests. Neonates with less than $24 \mathrm{~h}$ from the 3rd to the 6th broods were used. The evaluation of daphnia fitness and the validation of the test were achieved by performing the $24 \mathrm{~h}$ acute toxicity test with $\mathrm{K}_{2} \mathrm{Cr}_{2} \mathrm{O}_{7}$ as recommended by the OECD Guideline 202 and fully described by Fernandes et al. [36,37].

The acute toxicity tests were performed following the OEDC Guideline 202 [36]. For each treatment and respective controls, five replicates with five neonates each were tested. Daphnids were exposed to different dilutions of the treated and untreated solutions in a six well plate. For each replicate, $10 \mathrm{~mL}$ of the test solutions were used, corresponding to $2 \mathrm{~mL}$ per daphnid as recommended by the OECD Guideline [36]. The number of immobilized daphnia was registered after 24 and $48 \mathrm{~h}$ and the median effective concentration $\left(\mathrm{EC}_{50}\right)$ was calculated using the software GraphPad Prism8. All of the toxicity tests were performed within 1 month of the EO treatment and the samples were preserved under dark conditions at $-20^{\circ} \mathrm{C}$. Prior to the beginning of the tests, the samples were left to unfreeze at $4{ }^{\circ} \mathrm{C}$. 


\subsection{Physicochemical Determinations}

The characterization of samples was performed by measuring TOC and TN measured in a Shimadzu TOC-V CPH analyzer combined with a TNM-1 unit and by the determination of chemical oxygen demand (COD) using a closed reflux and titrimetric method according to standard procedures [38]. High performance liquid chromatography (HPLC) was also performed for MC determinations using a Shimadzu 20A Prominence HPLC system equipped with a SPD-M20A diode array detector, a CTO-20AC column oven and a LC-20AD pump and using a Purospher STAR RP18 endcapped column $(250 \times 4 \mathrm{~mm}$ (i.d.), $5 \mu \mathrm{m})$. The elution was performed isocratically with a mixture of formic acid aqueous solution $(0.05 \%)$ and acetonitrile, $50: 50(v / v)$, at a flow rate of $1 \mathrm{~mL} \mathrm{~min}^{-1}$ and $35^{\circ} \mathrm{C}$. The injection volume was $20 \mu \mathrm{L}$ and the detection wavelength was $262 \mathrm{~nm}$. The reagents were Sigma-Aldrich HPLC grade and ultrapure water (Milli-Q system) was utilized to prepare the solutions.

pH (HANNA, HI 931400) and conductivity (Mettler Toledo, SevenEasy S30K) were measured along the assays.

\section{Results and Discussion}

Figure 1 presents the normalized variation of MC and TOC concentrations with applied charge during the $\mathrm{EO}$ assays accomplished with different supporting electrolyte and applied current densities. When the influence of the supporting electrolyte was analyzed, the MC and TOC removal rates were higher for the solutions containing $\mathrm{NaCl}$. In fact, in the presence of chloride, $\mathrm{MC}$ was completely degraded during the initial period of the assays for both $j$ whereas in the presence of $\mathrm{Na}_{2} \mathrm{SO}_{4}$, the $\mathrm{MC}$ removal rate was lower and decreased along the assays. This faster degradation in the presence of chloride has been described in the literature for other contaminants and, according to the authors, is due to the additional indirect oxidation in the bulk of the solution by active chlorine species generated from the oxidation of chloride ions at the BDD [33,39].
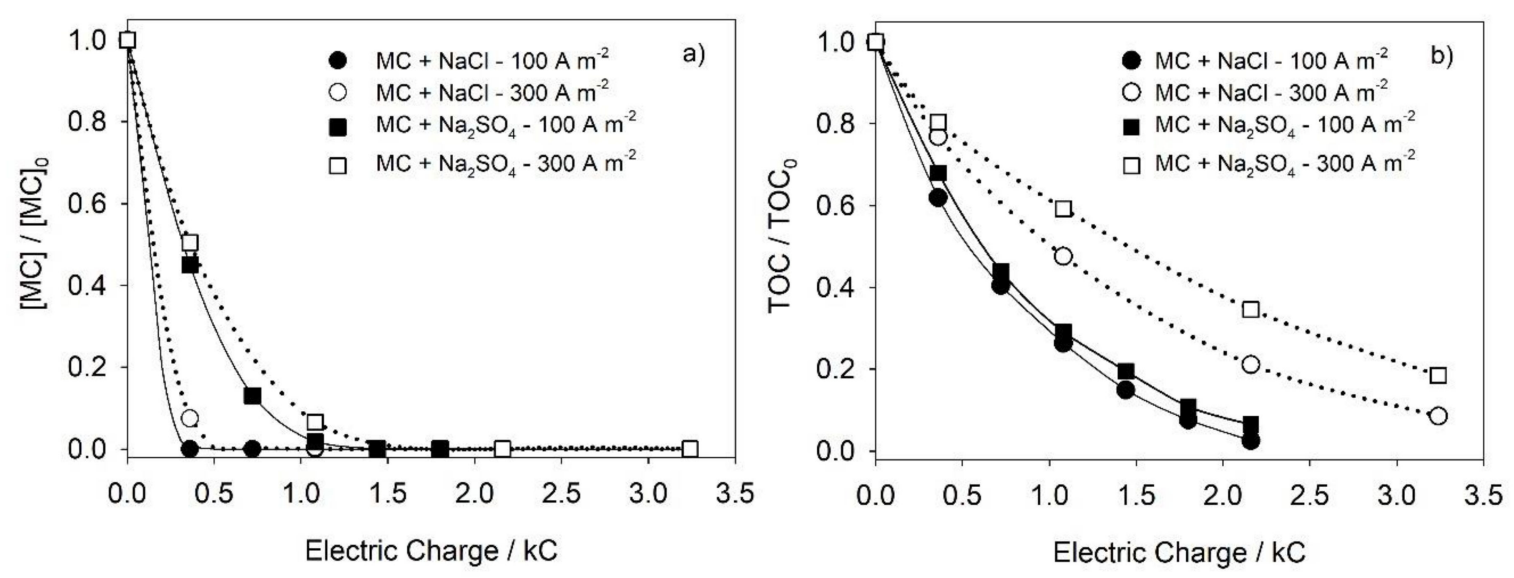

Figure 1. Variation with applied charge of the normalized (a) methiocarb (MC) concentration and (b) total organic carbon (TOC) for the electrochemical oxidation (EO) experiments performed at 100 and $300 \mathrm{~A} \mathrm{~m}^{-2}$ using $\mathrm{Na}_{2} \mathrm{SO}_{4}$ or $\mathrm{NaCl}$ as the supporting electrolyte.

To elucidate the reaction kinetics in both electrolytes, the decay in time of the MC concentration determined by HPLC for the first hour of the assays was analyzed. The MC degradation showed a first-order reaction mechanism with the following kinetic constants: $\mathrm{k}=0.28 \times 10^{-3} \mathrm{~s}^{-1}\left(\mathrm{Na}_{2} \mathrm{SO}_{4} \_100 \mathrm{~A} \mathrm{~m}^{-2}\right) ; \mathrm{k}=0.77 \times 10^{-3} \mathrm{~s}^{-1}\left(\mathrm{Na}_{2} \mathrm{SO}_{4} 300 \mathrm{~A} \mathrm{~m}^{-2}\right)$; $\mathrm{k}=1.6 \times 10^{-3} \mathrm{~s}^{-1}\left(\mathrm{NaCl} \_100 \mathrm{~A} \mathrm{~m}^{-2}\right) ; \mathrm{k}=1.7 \times 10^{-3} \mathrm{~s}^{-1}\left(\mathrm{NaCl} \_300 \mathrm{~A} \mathrm{~m}^{-2}\right)$. This showed that, in the chloride medium, the oxidation happened mainly in the bulk of the solution and, because the MC concentration was low, even at the lowest applied current density the chlorine active species formed were enough to oxidize MC at a very good reaction rate. Regarding oxidation in the presence of 
sulfate, the oxidation mechanism must be either by hydroxyl or sulfate radicals with a lower lifetime, thus giving more importance to MC diffusion towards the anode's surface.

Regarding the TOC, for the highest $j$, the difference between the removal rates when $\mathrm{NaCl}$ or $\mathrm{Na}_{2} \mathrm{SO}_{4}$ were used was more pronounced than at $100 \mathrm{~A} \mathrm{~m}^{-2}$. Regardless of that, $\mathrm{MC}$ and TOC removals were energetically more efficient at the lowest $j$. These results indicated that at $300 \mathrm{~A} \mathrm{~m}^{-2}, \mathrm{MC}$ and by-product oxidation through hydroxyl radicals were reduced and the oxidation by active chlorine species was enhanced, which was due to the higher amount of active chlorine species available at this $j$ and to the lower amount of hydroxyl radicals available, caused by the augmentation of secondary reactions such as the oxidation of the electrolyte or oxygen and hydrogen evolution [40]. Although the mentioned reactions were always present, their rate increased with applied current densities.

The different degradation mechanisms occurring when $\mathrm{NaCl}$ or $\mathrm{Na}_{2} \mathrm{SO}_{4}$ were used were also evidenced in $\mathrm{pH}$ variation along the assays (Figure 2a). When $\mathrm{NaCl}$ was used, an increase in $\mathrm{pH}$ during the initial period of the assays was found, followed by a decrease to below the initial value and ending in a plateau. The initial increase in $\mathrm{pH}$ observed was probably due to the chloride oxidation/water reduction and the subsequent decrease could be a result of the formation of by-products such as short chain carboxylic acids [17]. In the presence of $\mathrm{Na}_{2} \mathrm{SO}_{4}$, a decrease in $\mathrm{pH}$ during the initial period of the assays was observed with a subsequent tendency to a plateau.
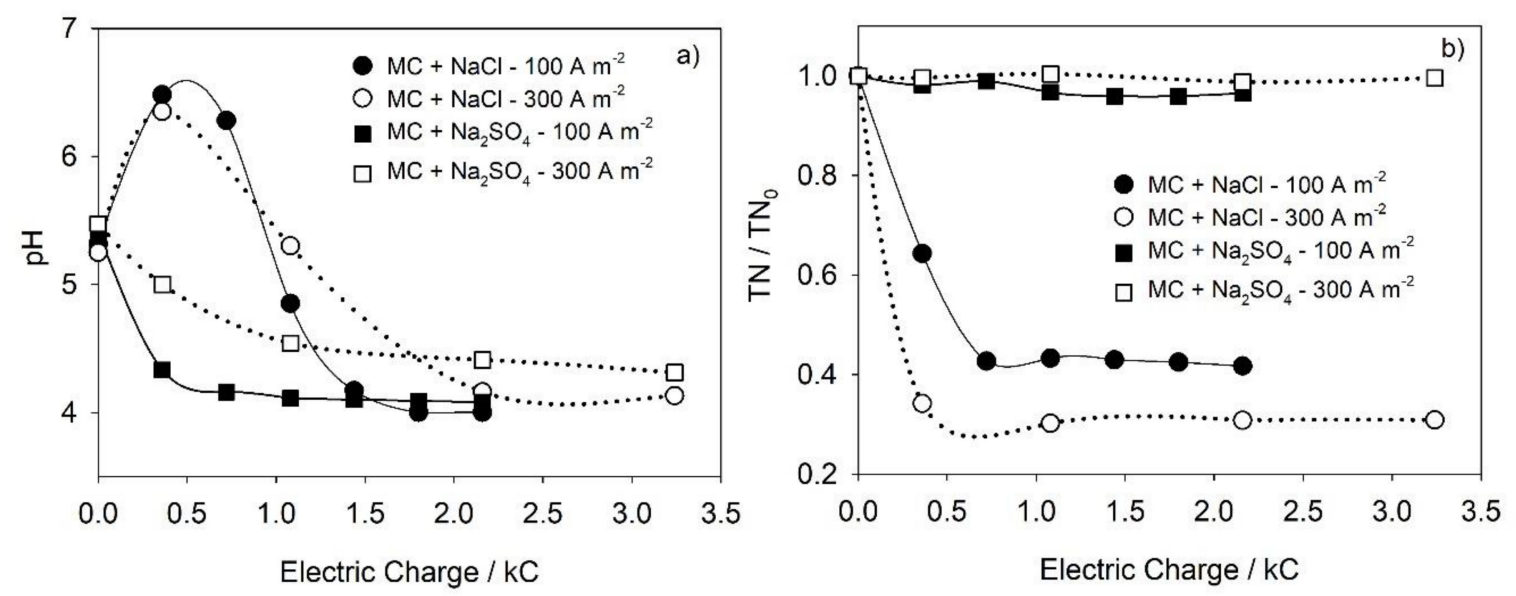

Figure 2. Variation with applied charge of the (a) $\mathrm{pH}$ and (b) normalized total nitrogen (TN) for the EO experiments performed at 100 and $300 \mathrm{~A} \mathrm{~m}^{-2}$ using $\mathrm{Na}_{2} \mathrm{SO}_{4}$ or $\mathrm{NaCl}$ as the supporting electrolyte.

As an MC molecule has nitrogen in its structure, TN variation during the assays was also assessed. A normalized TN variation with an applied charge, presented in Figure $2 b$, showed that in the presence of $\mathrm{Na}_{2} \mathrm{SO}_{4}$ no nitrogen removal occurred. However, when $\mathrm{NaCl}$ was used, $\mathrm{TN}$ concentration decreased by more than $50 \%$. According to the literature, organic nitrogen is converted to $\mathrm{NH}_{4}{ }^{+}$in the $\mathrm{EO}$ using a BDD anode, which in turn is oxidized mainly to nitrate and nitrogen gas as $\mathrm{NH}_{4}{ }^{+}$oxidation takes place by indirect oxidation through active chlorine species [41,42]. It was also observed that, for the solutions containing chloride, TN removal was energetically more efficient at the highest current density. These results agreed with the enhancement of the electrolyte oxidation reaction at a higher $j$ because more active chlorine species available lead to a higher $\mathrm{TN}$ removal rate.

As MC is a highly toxic compound, the ecotoxicological evaluation of the treatment methods applied to its degradation is mandatory. Thus, the ecotoxicity of the treated samples obtained in this study as well of the initial samples was evaluated towards Daphnia magna. As it can be perceived from Figure 3 and Figure S1 (Supplementary Material), the electrochemical oxidation treatment of methiocarb solutions led to a remarkable decrease in the acute toxicity towards Daphnia magna. In both MC solutions containing $\mathrm{Na}_{2} \mathrm{SO}_{4}$ or $\mathrm{NaCl}$, the initial toxicity was very high although solutions prepared with $\mathrm{NaCl}$ were slightly less toxic $\left(\mathrm{EC}_{50}=0.21 \%, 470.4 \mathrm{TUs}\right.$ against $\mathrm{EC}_{50}=0.27 \%, 370.9$ TUs for solutions prepared 
with $\mathrm{Na}_{2} \mathrm{SO}_{4}$ and $\mathrm{NaCl}$, respectively). Methiocarb is an acetylcholinesterase inhibitor pesticide widely used in agriculture as a molluscicide, acaricide and avicide and its toxicity towards aquatic invertebrates has already been reported [43]. Figure 3 a presents the $\mathrm{EC}_{50}$ results after $48 \mathrm{~h}$ of exposure for the different experimental conditions studied. The higher $\mathrm{EC}_{50}$ values were attained for the experiments performed at $100 \mathrm{~A} \mathrm{~m}^{-2}$ using $\mathrm{NaCl}$ as the supporting electrolyte. At these experimental conditions, an increase in $\mathrm{EC}_{50}$ from $0.27 \%$ to $62 \%$ was achieved after a $5 \mathrm{~h}$ assay $(1.8 \mathrm{kC})$. However, when the assay duration was extended for one more hour to $6 \mathrm{~h}(2.16 \mathrm{kC})$ in total, the $\mathrm{EC}_{50}$ decreased to $50 \%$. In solutions containing chloride, the increase in toxicity during the electrochemical treatment is usually attributed to the formation of chlorinated compounds [44,45], which exhibit a high octanol/water coefficient (Kow), thus affecting biological membranes and presenting higher toxicity for living organisms [37]. Furthermore, the formation of perchlorate at the final stage of the electrochemical process when using a BDD anode is well described in the literature [46-48]. According to Lacasa et al. [45], the hydroxyl radicals formed in large quantities during the electrolysis of aqueous solutions when a BDD anode is used in the presence of chlorides can be oxidized successively to different oxochlorinated compounds according to Equations (1)-(4).

$$
\begin{gathered}
\mathrm{Cl}^{-}+\mathrm{OH}^{\bullet} \rightarrow \mathrm{ClO}^{-}+\mathrm{H}^{+}+\mathrm{e}^{-} \\
\mathrm{ClO}^{-}+\mathrm{OH}^{\bullet} \rightarrow \mathrm{ClO}_{2}^{-}+\mathrm{H}^{+}+\mathrm{e}^{-} \\
\mathrm{ClO}_{2}^{-}+\mathrm{OH}^{\bullet} \rightarrow \mathrm{ClO}_{3}^{-}+\mathrm{H}^{+}+\mathrm{e}^{-} \\
\mathrm{ClO}_{3}^{-}+\mathrm{OH}^{\bullet} \rightarrow \mathrm{ClO}_{4}^{-}+\mathrm{H}^{+}+\mathrm{e}^{-}
\end{gathered}
$$
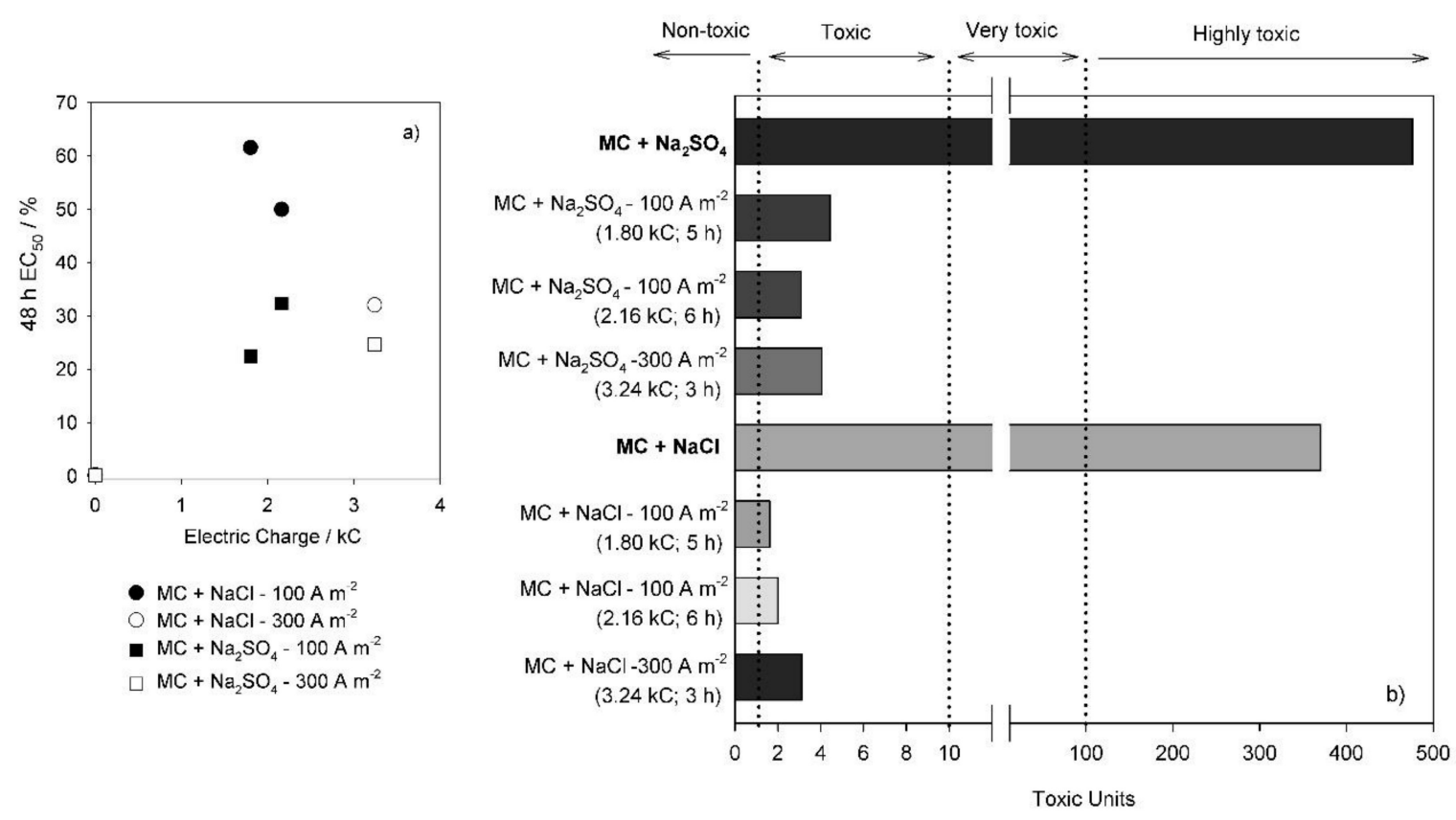

Figure 3. (a) $\mathrm{EC}_{50}$ results obtained for the treated solutions at 100 and $300 \mathrm{~A} \mathrm{~m}^{-2}$ using $\mathrm{Na}_{2} \mathrm{SO}_{4}$ or $\mathrm{NaCl}$ as the supporting electrolyte. (b) Comparison of the toxicity of the different methiocarb solutions in terms of toxic units before and after treatment at the different experimental conditions.

Attending that, in the last hour of the assay, the organic load in the solution is low and its oxidation is under mass transport control, the occurrence of the reactions described by Equations (1)-(4) will be enhanced and the perchlorate concentration in the solution, as the final oxidation product, will increase, explaining the increase in ecotoxicity found. The possible formation of organochlorinated compounds 
in the last hour of the assay, although in low concentration because the TOC was less than $1 \mathrm{mg} \mathrm{L}^{-1}$ at this point, could also be a possible explanation for the increased ecotoxicity.

Both perchlorate and organochlorinated compound formation can also explain the lower ecotoxicity reduction presented by the chloride-containing solutions treated at $300 \mathrm{~A} \mathrm{~m}^{-2}$. At the applied charge of $3.24 \mathrm{kC}\left(3 \mathrm{~h}\right.$ assay at $\left.300 \mathrm{~A} \mathrm{~m}^{-2}\right), \mathrm{EC}_{50}$ increased only to $32 \%$. At higher applied current densities, chloride oxidation and hydroxyl radical formation were enhanced, augmenting the occurrence of the reactions described by Equations (1)-(4) and the possible formation of organochlorinated compounds.

For the solutions prepared with sulfate at $100 \mathrm{~A} \mathrm{~m}^{-2}, \mathrm{EC}_{50}$ increased from $0.21 \%$ to $22 \%$ after a $5 \mathrm{~h}$ assay $(1.8 \mathrm{kC})$ and to $32 \%$ after $6 \mathrm{~h}(2.16 \mathrm{kC})$. These results agreed with the lower MC degradation rate observed for the solutions containing sulfate and indicated that at $1.8 \mathrm{kC}$ there were in the solution toxic MC degradation products that were being further oxidized to less or non-toxic compounds, decreasing the solution toxicity at $2.16 \mathrm{kC}$. Nevertheless, the increase in applied current density and charge did not result in a further decrease in toxicity. At the applied charge of $3.24 \mathrm{kC}$ ( $3 \mathrm{~h}$ assay at $\left.300 \mathrm{~A} \mathrm{~m}^{-2}\right), \mathrm{EC}_{50}$ increased only to $25 \%$ in the sulfate-containing solution. This result can be explained by the energy efficiency loss when $j$ was increased as observed for the TOC removal, mainly due to mass transport limitations.

In terms of toxic units (Figure $3 \mathrm{~b}$ ), it can be seen that, using $\mathrm{NaCl}$ as the supporting electrolyte, it was possible to reduce the toxicity more than $200 \times$ from 370.9 TUs to 1.6 TUs with $5 \mathrm{~h}$ treatment at $100 \mathrm{~A} \mathrm{~m}^{-2}$, whereas for the same conditions but using $\mathrm{Na}_{2} \mathrm{SO}_{4}$, the reduction was only of $107 \times$ from 470.4 TUs to 4.4 TUs. At the higher applied current density of $300 \mathrm{~A} \mathrm{~m}^{-2}$, the difference between the supporting electrolytes was less pronounced, with a similar reduction in toxicity of $120 \times$ versus $115 \times$ for $\mathrm{NaCl}$ and $\mathrm{Na}_{2} \mathrm{SO}_{4}$ containing solutions, respectively.

Overall, the results obtained clearly demonstrated the remarkable efficiency of EO treatment for MC complete degradation and its high potential for reducing the toxic ecological effects of this highly hazardous pesticide even when present in concentrations far above those currently reported for waters and wastewaters. According to Pablos et al. [35], the MC solutions went from being classified as highly toxic before treatment to toxic and very close to be considered non-toxic after EO treatment. Although the present study only addressed experiments at a laboratory scale, it offers a useful contribution to further develop the application of the electrochemical oxidation process at an industrial level. In fact, according to the results achieved, EO can be considered suitable for the remediation of contaminated industrial or agricultural wastewaters, enabling the elimination of $\mathrm{MC}$ and its adverse effects before they reach the aquatic environment.

\section{Conclusions}

Electrochemical oxidation with a BDD anode can effectively degrade methiocarb and its transformation by-products, reducing drastically the acute toxicity towards Daphnia magna. The MC electrodegradation mechanism depends on the species present in the solution and on the applied current density:

- In the presence of chloride, MC is rapidly transformed as result of its additional indirect oxidation by active chlorine species. These active chlorine species are responsible for the nitrogen elimination, above $50 \%$.

- In the presence of sulfate, the electrooxidation mechanism involves mainly hydroxyl radicals formed at the BDD surface leading to a slow MC elimination because the oxidation rate depends on the MC diffusion to the anode's surface. No nitrogen removal was observed using this supporting electrolyte.

- An increase in current density enhances secondary reaction rates, thus decreasing the energy efficiency. An exception is nitrogen removal in chloride-containing solutions, which is promoted by the increased amount of active chlorine species. 
- Chloride-containing solutions lead to higher toxicity reductions than sulfate-containing solutions most likely due to the faster MC degradation and of its transformation products when $\mathrm{NaCl}$ is used.

- In chloride-containing solutions, the increase in applied electric charge due to the increase in assay duration or applied current density leads to a lower decrease in ecotoxicity probably due to the formation of perchlorate and organochlorinated compounds.

At optimized experimental conditions, the EO process offers a suitable solution for the treatment and elimination of undesirable ecological effects of MC contaminated industrial or agricultural wastewaters, ensuring that this priority substance is not transferred to the aquatic environment.

Supplementary Materials: The following are available online at http:/www.mdpi.com/2076-3417/10/21/7435/ s1, Figure S1: Number of immobilized daphnids after 24 and $48 \mathrm{~h}$ of exposure to the different treatments. Immobilization refers to the inability of animals that are not able to swim within 15 seconds, after gentle agitation of the test vessel [1].

Author Contributions: Conceptualization, A.L.; methodology, A.F. and A.C.S.; validation, A.F. and A.C.S.; investigation, C.P., S.C. and C.F.; resources, M.R.P. and L.C.; writing-original draft preparation, A.F. and A.C.S.; writing-review and editing, M.R.P., M.J.P., L.C. and A.L.; visualization, M.J.P.; supervision, A.L.; project administration, A.F. All authors have read and agreed to the published version of the manuscript.

Funding: This research was funded by Fundação para a Ciência e a Tecnologia, FCT, through UID Fiber Materials and Environmental Technologies (FibEnTech), project UIDB/00195/2020. Further financial support was provided by funds from the Health Sciences Research Center (CICS-UBI) through National Funds by FCT (UID/Multi/00709/2019).

Acknowledgments: A.C.S. acknowledges University of Aveiro for funding in the scope of the framework contract foreseen in the numbers 4, 5 and 6 of the article 23, of the Decree-Law 57/2016, of August 29, changed by Law 57/2017, of July 19 and project CICECO-Aveiro Institute of Materials, UIDB/50011/2020 \& UIDP/50011/2020, financed by national funds through the FCT/MEC and when appropriate co-financed by FEDER under the PT2020 Partnership Agreement.

Conflicts of Interest: The authors declare no conflict of interest. The funders had no role in the design of the study; in the collection, analyses, or interpretation of data; in the writing of the manuscript or in the decision to publish the results.

\section{References}

1. Ebele, A.J.; Abdallah, M.A.-E.; Harrad, S. Pharmaceuticals and personal care products (PPCPs) in the freshwater aquatic environment. Emerg. Contam. 2017, 3, 1-16. [CrossRef]

2. Westlund, P.; Yargeau, V. Investigation of the presence and endocrine activities of pesticides found in wastewater effluent using yeast-based bioassays. Sci. Total Environ. 2017, 607, 744-751. [CrossRef] [PubMed]

3. Krieg, S.A.; Shahine, L.K.; Lathi, R.B. Environmental exposure to endocrine-disrupting chemicals and miscarriage. Fertil. Steril. 2016, 106, 941-947. [CrossRef] [PubMed]

4. Puckowski, A.; Mioduszewska, K.; Łukaszewicz, P.; Borecka, M.; Caban, M.; Maszkowska, J.; Stepnowski, P. Bioaccumulation and analytics of pharmaceutical residues in the environment: A review. J. Pharm. Biomed. Anal. 2016, 127, 232-255. [CrossRef] [PubMed]

5. Commission Implementing Decision (EU) 2018/840. Off. J. Eur. Union 2018, L141/9-L141/12. Available online: https://eur-lex.europa.eu/legal-content/EN/TXT/PDF/?uri=CELEX:32018D0840\&rid=7 (accessed on 12 June 2020).

6. Campo, J.; Masiá, A.; Blasco, C.; Picó, Y. Occurrence and removal efficiency of pesticides in sewage treatment plants of four Mediterranean River Basins. J. Hazard. Mater. 2013, 263, 146-157. [CrossRef] [PubMed]

7. Masiá, A.; Ibáñez, M.; Blasco, C.; Sancho, J.; Picó, Y.; Hernández, F.H. Combined use of liquid chromatography triple quadrupole mass spectrometry and liquid chromatography quadrupole time-of-flight mass spectrometry in systematic screening of pesticides and other contaminants in water samples. Anal. Chim. Acta 2013, 761, 117-127. [CrossRef] [PubMed]

8. Fytianos, K.; Pitarakis, K.; Bobola, E. Monitoring of N -methylcarbamate pesticides in the Pinios River (central Greece) by HPLC. Int. J. Environ. Anal. Chem. 2006, 86, 131-145. [CrossRef] 
9. Squillace, P.J.; Scott, J.C.; Moran, M.J.; Nolan, B.T.; Kolpin, D.W. VOCs, pesticides, nitrate, and their mixtures in groundwater used for drinking water in the United States. Environ. Sci. Technol. 2002, 36, 1923-1930. [CrossRef]

10. World Health Organization. The WHO Recommended Classification of Pesticides by Hazard and Guidelines to Classification 2009; World Health Organization: Geneva, Switzerland, 2010; ISBN 978-92-4-154796-3.

11. Cruz-Alcalde, A.; Sans, C.; Esplugas, S. Exploring ozonation as treatment alternative for methiocarb and formed transformation products abatement. Chemosphere 2017, 186, 725-732. [CrossRef]

12. Commission Implementing Regulation (EU) 2019/1606. Off. J. Eur. Union 2019, L250/53-L250/55. Available online: https:/eur-lex.europa.eu/legal-content/EN/TXT/PDF/?uri=CELEX:32019R1606\&from=GA (accessed on 12 June 2020).

13. Camacho, F.G.; De Souza, P.A.L.; Martins, M.L.; Benincá, C.; Zanoelo, E.F. A comprehensive kinetic model for the process of electrochemical peroxidation and its application for the degradation of trifluralin. J. Electroanal. Chem. 2020, 865, 114163. [CrossRef]

14. Santos, G.D.O.; Eguiluz, K.I.; Salazar-Banda, G.R.; Saez, C.; Rodrigo, M.A. Testing the role of electrode materials on the electro-Fenton and photoelectro-Fenton degradation of clopyralid. J. Electroanal. Chem. 2020, 871, 114291. [CrossRef]

15. Ferreira, M.B.; Souza, F.; Muñoz-Morales, M.; Sáez, C.; Cañizares, P.; Martínez-Huitle, C.; Rodrigo, M.A. Clopyralid degradation by AOPs enhanced with zero valent iron. J. Hazard. Mater. 2020, 392, 122282. [CrossRef]

16. Vagi, M.C.; Petsas, A.S. Recent advances on the removal of priority organochlorine and organophosphorus biorecalcitrant pesticides defined by Directive 2013/39/EU from environmental matrices by using advanced oxidation processes: An overview (2007-2018). J. Environ. Chem. Eng. 2020, 8, 102940. [CrossRef]

17. Moreira, F.C.; Boaventura, R.A.; Brillas, E.; Vilar, V.J. Electrochemical advanced oxidation processes: A review on their application to synthetic and real wastewaters. Appl. Catal. B Environ. 2017, 202, 217-261. [CrossRef]

18. Barbosa, M.O.; Moreira, N.F.; Ribeiro, A.R.; Pereira, M.F.; Silva, A.M.T. Occurrence and removal of organic micropollutants: An overview of the watch list of EU Decision 2015/495. Water Res. 2016, 94, 257-279. [CrossRef]

19. Petrovic, M.; Gonzalez, S.; Barceló, D. Analysis and removal of emerging contaminants in wastewater and drinking water. TrAC Trends Anal. Chem. 2003, 22, 685-696. [CrossRef]

20. Qiang, Z.; Tian, F.; Liu, W.; Liu, C. Degradation of methiocarb by monochloramine in water treatment: Kinetics and pathways. Water Res. 2014, 50, 237-244. [CrossRef]

21. Tian, F.; Qiang, Z.; Liu, W.; Ling, W. Methiocarb degradation by free chlorine in water treatment: Kinetics and pathways. Chem. Eng. J. 2013, 232, 10-16. [CrossRef]

22. Tian, F.; Qiang, Z.; Liu, C.; Zhang, T.; Dong, B. Kinetics and mechanism for methiocarb degradation by chlorine dioxide in aqueous solution. Chemosphere 2010, 79, 646-651. [CrossRef]

23. Yang, L.; Li, M.; Li, W.; Jiang, Y.; Qiang, Z. Bench- and pilot-scale studies on the removal of pesticides from water by VUV/UV process. Chem. Eng. J. 2018, 342, 155-162. [CrossRef]

24. Gligorovski, S.; Strekowski, R.; Barbati, S.; Vione, D. Environmental Implications of Hydroxyl Radicals $(\bullet \mathrm{OH})$. Chem. Rev. 2015, 115, 13051-13092. [CrossRef] [PubMed]

25. Martínez-Huitle, C.A.; Panizza, M. Electrochemical oxidation of organic pollutants for wastewater treatment. Curr. Opin. Electrochem. 2018, 11, 62-71. [CrossRef]

26. Silva, L.M.; Dos Santos, R.P.A.; Morais, C.C.O.; Vasconcelos, C.L.; Martínez-Huitle, C.A.; Castro, S.S.L. Anodic Oxidation of the Insecticide Imidacloprid on Mixed Metal Oxide (RuO2-TiO2and IrO2-RuO2-TiO2) Anodes. J. Electrochem. Soc. 2017, 164, E489-E495. [CrossRef]

27. Dhaouadi, A.; Adhoum, N. Degradation of paraquat herbicide by electrochemical advanced oxidation methods. J. Electroanal. Chem. 2009, 637, 33-42. [CrossRef]

28. Martínez-Huitle, C.A.; De Battisti, A.; Ferro, S.; Reyna, S.; Cerro-López, M.; Quiro, M.A. Removal of the Pesticide Methamidophos from Aqueous Solutions by Electrooxidation using $\mathrm{Pb} / \mathrm{PbO} 2, \mathrm{Ti} / \mathrm{SnO} 2$, and $\mathrm{Si} / \mathrm{BDD}$ Electrodes. Environ. Sci. Technol. 2008, 42, 6929-6935. [CrossRef]

29. Dao, K.C.; Yang, C.-C.; Chen, K.-F.; Tsai, Y.-P. Recent Trends in Removal Pharmaceuticals and Personal Care Products by Electrochemical Oxidation and Combined Systems. Water 2020, 12, 1043. [CrossRef] 
30. Pueyo, N.; Ormad, M.P.; Miguel, N.; Kokkinos, P.; Ioannidi, A.; Mantzavinos, D.; Frontistis, Z. Electrochemical oxidation of butyl paraben on boron doped diamond in environmental matrices and comparison with sulfate radical-AOP. J. Environ. Manag. 2020, 269, 110783. [CrossRef]

31. Ganiyu, S.O.; Martínez-Huitle, C.A. Nature, Mechanisms and Reactivity of Electrogenerated Reactive Species at Thin-Film Boron-Doped Diamond (BDD) Electrodes During Electrochemical Wastewater Treatment. ChemElectroChem 2019, 6, 2379-2392. [CrossRef]

32. Martínez-Huitle, C.A.; Brillas, E.; Einaga, Y.; Farrell, J. Trends in Synthetic Diamond for Electrochemical Applications. ChemElectroChem 2019, 6, 4330-4331. [CrossRef]

33. Pereira, G.F.; Rocha-Filho, R.C.; Bocchi, N.; Biaggio, S.R. Electrochemical degradation of bisphenol A using a flow reactor with a boron-doped diamond anode. Chem. Eng. J. 2012, 198, 282-288. [CrossRef]

34. Ma, M.; Li, J.; Wang, Z. Assessing the Detoxication Efficiencies of Wastewater Treatment Processes Using a Battery of Bioassays/Biomarkers. Arch. Environ. Contam. Toxicol. 2005, 49, 480-487. [CrossRef] [PubMed]

35. Pablos, M.V.; Martini, F.; Fernández, C.; Babín, M.; Herraez, I.; Miranda, J.; Martínez, J.; Carbonell, G.; San-Segundo, L.; García-Hortigüela, P.; et al. Correlation between physicochemical and ecotoxicological approaches to estimate landfill leachates toxicity. Waste Manag. 2011, 31, 1841-1847. [CrossRef] [PubMed]

36. OECD Guideline for Testing of Chemicals_Daphnia so., Acute Immobilisation Test; OECD: Paris, France, 2004.

37. Fernandes, A.; Pastorinho, M.R.; Sousa, A.C.; Silva, W.; Silva, R.; Nunes, M.J.; Rodrigues, A.; Pacheco, M.; Ciríaco, L.; Lopes, A. Ecotoxicological evaluation of electrochemical oxidation for the treatment of sanitary landfill leachates. Environ. Sci. Pollut. Res. 2018, 26, 24-33. [CrossRef] [PubMed]

38. Eaton, A.; Clesceri, L.; Rice, E.; Greenberg, A.; Franson, M.A. Standard Methods for Examination of Water and Wastewater, 21st ed.; American Public Health Association: Washington, DC, USA, 2005.

39. Murugananthan, M.; Yoshihara, S.; Rakuma, T.; Shirakashi, T. Mineralization of bisphenol A (BPA) by anodic oxidation with boron-doped diamond (BDD) electrode. J. Hazard. Mater. 2008, 154, 213-220. [CrossRef] [PubMed]

40. Panizza, M.; Cerisola, G. Direct And Mediated Anodic Oxidation of Organic Pollutants. Chem. Rev. 2009, 109, 6541-6569. [CrossRef]

41. Fernandes, A.; Coelho, J.; Ciríaco, L.; Pacheco, M.; Lopes, A. Electrochemical wastewater treatment: Influence of the type of carbon and of nitrogen on the organic load removal. Environ. Sci. Pollut. Res. 2016, 23, 24614-24623. [CrossRef]

42. Perez, G.; Saiz, J.; Ibañez, R.; Urtiaga, A.; Ortiz, I. Assessment of the formation of inorganic oxidation by-products during the electrocatalytic treatment of ammonium from landfill leachates. Water Res. 2012, 46, 2579-2590. [CrossRef]

43. Arena, M.; Auteri, D.; Barmaz, S.; Brancato, A.; Brocca, D.; Bura, L.; Cabrera, L.C.; Chiusolo, A.; Civitella, C.; Marques, D.C.; et al. Conclusion on the peer review of the pesticide risk assessment of the active substance methiocarb. EFSA J. 2018, 16, e05429. [CrossRef]

44. Costa, C.R.; Botta, C.M.; Espíndola, E.L.; Olivi, P. Electrochemical treatment of tannery wastewater using DSA@electrodes. J. Hazard. Mater. 2008, 153, 616-627. [CrossRef]

45. Gotsi, M.; Kalogerakis, N.; Psillakis, E.; Samaras, P.; Mantzavinos, D. Electrochemical oxidation of olive oil mill wastewaters. Water Res. 2005, 39, 4177-4187. [CrossRef]

46. Lacasa, E.; Llanos, J.; Cañizares, P.; Rodrigo, M.A. Electrochemical denitrificacion with chlorides using DSA and BDD anodes. Chem. Eng. J. 2012, 184, 66-71. [CrossRef]

47. Sánchez-Carretero, A.; Sáez, C.; Cañizares, P.; Rodrigo, M.A. Electrochemical production of perchlorates using conductive diamond electrolyses. Chem. Eng. J. 2011, 166, 710-714. [CrossRef]

48. Polcaro, A.; Vacca, A.; Mascia, M.; Ferrara, F. Product and by-product formation in electrolysis of dilute chloride solutions. J. Appl. Electrochem. 2008, 38, 979-984. [CrossRef]

Publisher's Note: MDPI stays neutral with regard to jurisdictional claims in published maps and institutional affiliations. 